\title{
The Impact of Social Grants on Rural Women: Perspectives from ABET Practitioners
}

\author{
Lineo Johnson \\ Mpho Dichaba \\ Dept. of ABET \& Youth Development, College of Education \\ University of South Africa \\ Email address: dichamm@unisa.ac.za
}

\section{Doi:10.5901/mjss.2013.v4n13p541}

\section{Abstract}

The most recent census information available, as well as other reports and studies reveal that out of a population of about 52 million South Africans, approximately 30 percent live on social grants. This translates to at least 15.6 million social grant recipients countrywide. This study examines how social grants have contributed to the well-being and especially livelihoods of rural people. It also examines how the grants have enabled and empowered recipients, encouraged self-reliance and created opportunities for socioeconomic growth and development towards poverty alleviation for rural recipients. Proponents of Adult Basic Education and Training (ABET) tend to link issues of education and development to literacy. This study examines how social grants contribute to improvements in families' livelihoods and the well-being of individuals who receive them. In addition, it seeks to establish whether there is a link between the provision of social grants, as a social policy model, and literacy, development and education. While the social grant is meant to bridge economic disparities by assisting the poor, this study is located at an intersection of two schools of thought about this policy - those in support of and those against it. Jeffrey Sachs' Millennium Villages Project underpins the theoretical framework of this study as it gives hope for those critics who believe that Africa will forever be dependent on foreign aid and hand-outs. Qualitative and document analysis methods were used to collate and analyse journals and diaries kept by grant recipients in fifteen (15) rural households in the Free State over a period of two years. The main findings of the study reveal that social grants, as an economic intervention, are contributing substantively towards poverty reduction. However, the recipients feel that the social grant is a gift from government and believe that it will be forfeited, if they become self-reliant. The study concludes that more income-generating activities should be encouraged through the provision of loans or seed-funds as CARE-South Africa had done in their community development interventions to grant recipients. Social grants are only a means of survival, but community education can bring about for development - along with other adult education programmes - and is a key element in addressing sustainable development.

Keywords: social grants, self-reliance, poverty reduction, economic intervention, hand-outs.

\section{Introduction and Background}

Since the transition to a new political dispensation in 1994, the post-apartheid South African government has been internationally commended for creating a conducive environment for the alleviation of poverty through various national legal and policy frameworks. In this regard Thompson (2001) mentions the Reconstruction and Development Programme (RDP), later replaced by Growth Employment and Redistribution (GEAR) policy. The author indicates that through this policy evolution, the Mandela government was able to increase the annual budgetary allocations for welfare services and some progress was made in poverty alleviation. However, he also notes with concern promises yet unfulfilled where he is convinced too little was achieved, where the majority are still in similar marginalised conditions as before 1990. According to Thompson about 72 percent of the poor lived in rural areas; and although poverty was not confined to one racial group, it was concentrated among Africans of whom 61 percent were still poor. (Thompson (2001:275).

An observation that was made during President Mbeki's era was that the economic gap between the rich and the poor continued to widen. In order to alleviate abject poverty, the budget included hand-outs in the form of pensions, housing subsidies and childcare benefits. Thompson (2001), Statistics South Africa (2012) also featured on www.statisticssouthafrica.org and the National Development Plan: Vision for 2030 (2011) concur that much has not changed because the statistics still show the disparity where out of a population of about 52 million South Africans, about 30 percent live on social grants. Thus, at least 16 million South Africans are recipients of social grants.

This study examined how social grants are used on monthly basis by their recipients, particularly rural women, in Thaba-Nchu in the Free State Province in South Africa. The article starts with giving an overview of what social grants 
are understood within the South African context. There are misconceptions around social grants whereby some South Africans think even able-bodied people are taking advantage of them, by simply not trying hard enough to find employment. Other views social grants as poverty alleviation interventions bridging the gap between the rich and the poor. The paper discusses the effects of social grants and their financial implication on the economy of South Africa, defining the country into a welfare state model of social policy. Social grants' contribution towards the Millennium Development Goals (MDGs) are also argued to show-case how people's lives have improved, thus contributing to the household livelihoods and safety nets.

A case study method used to collect data by an international development agency CARE-South Africa provides a simple down-to-earth strategy on teaching rural women a simplified use of journal or diary to record their household earnings using social grants and other income-generating activities. The study concludes that foreign aid interventions and social grants should be seen as intermediate strategies towards poverty alleviation, where sustainable community development projects are well planned and implemented. Social grants in South Africa are defined in two categories, that is, cash and in-kind social grants. According to a recent study by Progressus \& Gordon (2012) under the banner of the FinMark Trust and the National Development Plan (NDP): Vision for 2030 (2011), the main objectives of social grants are

- to reduce poverty among groups who are not expected to participate fully in the labour market, including the elderly, those with disabilities, unemployed women and children, and

- to increase investment in health, education and nutrition, so as to increase economic growth and development.

\subsection{Types of social grants}

There are seven types of social grants in South Africa:

1. The State Old Age Pension (SOAP) provides support to men over the age of 65 and women 60 and over.

2. The Disability Grant (DG) provides support to adults with disabilities.

3. The Child Support Grant provides support to families with children under the age of 18.

4. The Foster Child Grant provides support to families with children below the age of 18, who are in foster care.

5. The Care Dependency Grant provides additional support to families with children below the age of 18 , with disabilities.

6. The War Veterans Grant provides support to a former soldier who fought in the First World War (1914 - 1918), Second World War $(1939-1945)$ or the Korean War and is unable to support him/herself.

7. The Grant in Aid provides support to a recipient of SOAP or the War Veteran Grant, who needs full time care by another person. (Progressus \& Gordon, 2012; NDP, 2011)

In order to qualify for any of the above grants, recipients have to meet legally stipulated requirements and policy criteria. Applicants are screened by the Department of Social Development through its implementing agency, the South African Social Security Agency (SASSA). The aim of this article is to report on:

- whether social grants, as a social policy model, is linked or associated with teenage mothers' literacy level and other social factors

- how social grants have contributed to the well-being and livelihoods of teenage mothers

- whether social grants have enabled and empowered recipients, encouraged self-reliance and created opportunities for socioeconomic growth and development towards poverty alleviation for rural teenage mothers.

\section{Assumptions and Perceptions about Social Grants}

The recent study by Progressus \& Gordon (2012) reveals that the social grants recipients "feel grants are a gift from government, and should therefore be spent and not saved" (p.78). If grants are saved, then recipients fear they might lose the benefit or forfeit it if it is not used for the intended purpose. The purpose of a comprehensive system of social security, as implemented by the Department of Social Development and the policy underpinning rural development, is to alleviate and reduce poverty, vulnerability, social exclusion and inequality, while simultaneously embarking on sustainable socioeconomic interventions. The perception about social grants by recipients then defeats the purposes for which the policy is intended or understood.

There is a misconception that some teenagers deliberately fall pregnant because, through child-bearing, they can gain access to the monthly social grants. This misconception can be attributed to illiteracy, social exclusion and under- 
development in our communities. How does illiteracy contribute to this misconception? The section below partly responds to the concern.

\subsection{Fatherless children and social grants}

There are various factors that contribute to the increasing number of social grants recipients in poor communities. The historical effects of the migrant labour systems in Southern Africa, unemployment and the high rate of HIV and AIDS (although in South Africa statistics show that the HIV and AIDS related deaths have drastically reduced - increasing life expectancy to 60 years) adult mortality are cited as contributing factors. The high morbidity and mortality rates among adults as a result of social ills, poverty, violence, and crime and car accidents have resulted in growing numbers of orphans and vulnerable children.

A study by Richter and Morrell (2008) contends that there is no such thing as a fatherless child. Every child has a father somewhere, even if the child does not live with its father or not see him very often. With regard to the status and well-being of children in South Africa, the NDP (2011:338) reports that only 27 percent of African (black) children live with their biological parents, in other words, 73 percent of African children are fatherless. While statistics might seem alarming, we should not forget that it is also not unusual among certain cultures for siblings, grandparents or other members of the family to act as guardians if the parents are unable financially or otherwise to take care of the child. Richter and Morrell (2008) illustrate a vicious cycle of poverty whereby unemployed, uneducated young women of poor families have children raise their, fatherless, children in poor conditions; in turn, these children, also become teenage parents and later become poor young adults. This research aims to investigate whether the combination of illiteracy, poverty and under-development in household livelihood security indeed contribute to an increase in teenage pregnancy and motherhood and the high number of fatherless children. Notably, South African children are protected by international conventions, protocols and the South African Constitution. The family legal system also provides protection for children. However, practically, it has been proven that tracing absent fathers takes its toll on single women, who usually prefer to ignore the absent partner and resort to quick-fix social grants outlet. The phenomenon of absent fathers in South Africa is indeed a cause for concern.

\section{Social Grants and a Welfare State}

The concept of social welfare states dates as far back as 1800s. According to Heintz and Lund (2012) welfare states are defined as governments which play a key role in the protection and promotion of economic and social well-being of its citizens. It is based on the principles of equality of opportunity, equitable distribution of wealth, and public responsibility for those unable to avail themselves of the minimal provisions for a good life. Primarily, the purpose of the welfare state is to create greater economic equality or to ensure at least a certain minimum standard of living for all citizens, through the implementation of policies to tackle socioeconomic inequalities. The debate on what constitutes a welfare state is a huge one and beyond the scope of this study. However, the statistics of South Africa's welfare contributions reflect a phenomenal increase in the past 15 to 20 years, both in terms of size and scope of the payments offered.

The under-development and rural nature of most of the former apartheid-era homelands compelled the new democratic South African government to exert all its energies in fast-tracking development efforts in these areas. The majority of households in the social security grants programme bracket are located in the former homelands, rural and semi-urban areas and black townships (NDP 2011). Through social welfare grants the country envisage that it will be able to attain this developmental goal, by investing resources where they are needed the most, in this way, improve the levels of inequality and poverty conditions. The government's Rural Development and Land Reform, Strategic Plan (2009-2012:36) states that "economic growth has to be promoted and the creation of work is essential to boost further growth". This mandate suggests that poverty alleviation interventions should be of sustainable nature; hence development interventions should not be only a humanitarian reaction. Social grants should therefore contribute in poverty reduction by ensuring that the recipients spend them responsibly while also thinking of other creative and innovative means towards their livelihoods and safety nets. Poverty alleviation should be seen and understood as a longterm sustainable development intervention. This process should be augmented by social welfare services such as social grants 


\section{Social Grants and the MDGs Framework}

With only 2 years left before the Millennium Development Goals (MDGs) 2015 deadline, countries are forecasting their implementation-pass rate. The eight socioeconomic MDGs include targets for reducing poverty and hunger; providing better access to health care, water and education; creating equal opportunities for women; and protecting the environment, as outlined in UNISA Reader (2009). The majority of the countries particularly in the Southern African Development Community (SADC) are not expected to achieve the goals by 2015. While some are struggling to meet the 2015 deadline, South Africa is projected to be on track. This is largely due to its social welfare interventions, which other countries in the region cannot afford for its citizens. A constant state of influx of former miners and their families from neighbouring countries such as Lesotho, Mozambique, Namibia, Malawi and Botswana still cross the borders to access social grants in South Africa.

Economic analyst of the MDGs, Jeffrey Sachs is featured as an optimist in the Millennium Villages Project. The Jeffrey Sachs Millennium Villages Project confounds critics who believe Africa will forever be dependent on aid and hand-outs. He rather takes optimistic lenses at the achievements in poverty alleviation and living conditions of people in countries such as Ghana, Kenya and South Africa. He encouraged other countries to learn from the success stories where the MDGs have positively impacted on the lives of the people (www.millenniumvillages.org). Lessons on how these countries have succeeded can be used by others. Some of the factors that contribute to the success of the countries can be attributed to insight about how best to apply aid to promote gains, rather than dependency. Similar principle can apply with social grants. If used properly they can promote gains and not create dependency.

Development has highlighted the vulnerability of the poor, uprooted traditional lifestyles and has led to social polarisation. The gains mentioned underscore that the MDGs economic development goals can be achieved through the provision of welfare services including social grants. However, the provision of social grants should be done with caution, and should be combined with long-term development plans to avoid dependency and to create sustainable development within communities.

While the motivation for social grants is to bridge the economic gap created by apartheid, this study is located at an intersection of two schools of thought. There are some scholars who believe social grants have indeed reduced poverty and improved living conditions of previously marginalised communities and households. There are also other scholars who think social grants create dependency and create casualties - communities that forever depend on handouts, social grants and cannot think of how they can develop themselves. Two recent surveys on social grants conducted under the banner of Progressus \& Gordon (2012) reveal that social grants have had a positive impact on the outcomes for children in South Africa. The South African social welfare model is commended and compares favourably with countries like Mexico and Brazil, where poverty has dramatically reduced. Largely this is because social grants in general, have significantly contributed to a reduction of poverty level within a short-time. This observation is according to Heinz and Lund (2012).

Scholars who are against social grants argue that the grants are becoming an economic burden on taxpayers who are continually required to increase their remittances to meet the escalating demands of government. According to the department of Social Development www.socialdevelopment.org.za it is estimated that the 2010/2011 social grant expenditure was about R89 billion, representing a 12 percent annual increase from previous years. The critics of the welfare state advocate for countries, particularly in developing world, to promote developmental states, where communities become self-reliant and, hence, establish sustainable livelihoods and development. The critics further argue that social grants reduce countries into welfare states where there is perpetual dependency, hence, human dignity and a sense of ownership and sustainable development is compromised.

Jeffrey Sachs and other optimists view poverty alleviation interventions as a means to tackle the MDGs. The NDP: Vision for 2030 (2011) proposes a fundamental paradigm shift for South Africa from being a welfare-cum-developmental state to a capable developmental state. The NDP observes that the foundations for a capable state are to address weaknesses and challenges that constrain the state's ability to pursue developmental objectives. It further dissuades stakeholders from adopting quick-fix methods and strategies that do not pursue long-term sustained focus in tackling economic challenges and advises that the move from a developmental to a capable state paradigm will balance the inequalities of the past by the year 2030.

\section{Research Approach and Methodology}

Rural development in South Africa can never be a one-size-fits-all concept. Rural areas have different, diverse and 
unique features, challenges, cultures, economic and developmental needs. A holistic understanding of historical, social, cultural and economic contexts helps researchers when they are involved in knowledge-generation of these diverse environments. This study from which this article draws, adopted a qualitative approach where the expenditure patterns of recipients were examined. Simplified household financial journals or diaries were studied over a period of time to assess the spending patterns of each household, including school costs. This involved talking to social grant recipients, particularly households with teenage mothers, about their personal spending and experiences in handling money/funds/finances. It also included details about the daily, weekly, monthly, yearly data generated through household financial needs; income and spending themes.

However, some quantitative data were also generated where household financial records; income and spending records were generated through the use of simple improvised journals and diaries that were given to the selected participants. Both qualitative and quantitative data from journals were triangulated. Storytelling, through open-ended interviews, was conducted with 30 social grants recipients between the ages of 19 to 55 years on how they spend their remittances on monthly basis. The participants were each given a diary or a journal to write their life-stories and to make notes about how they have spent their social grants each month. This study was conducted in Thaba-Nchu in the Free State, one of nine geographical provinces in South Africa. Thaba-Nchu comprises various rural villages, classified as northern and southern trusts. There are 20 villages in the northern trust and 25 in the southern trust $-\mathrm{a}$ total of 45 villages. Rural villages have local authority leadership - traditional chiefs, indunas ${ }^{1} /$ headmen- $^{2}$ and local councillors, provincial government departments and civil society organisations serving and providing services in the areas. This leadership cadre interacts with social grant recipients on a regular basis. Their interaction influences their perceptions and understanding of how social grants are used to contribute to the household economy and rural livelihoods. A questionnaire was distributed to two local chiefs, two local councillors and two CARE-South Africa international NGO volunteers. They were classified as key informants in the study.

\section{The Findings}

Social grants recipients are pensioners and war veterans; children, care-givers, women, sick and disabled persons. The Gordon (2012) study and the NDP (2011) reveal that the majority of social grant recipients are women/female. The 30 social grants recipients participants were each given a diary or a journal that the kept for a period of two years. The journal technique was found to be effective, not only as a data collection method, but it also enhanced the numeracy skills of the participants. The project took place over two years and it generated a massive amount of data, notes, stories and experiences of the recipients and their households' spending patterns. For two years, every three months, the diaries were collated and recorded. Following is an outcome of one of the diary-keepers: Mateboho, (not her real name) a 19year old mother, is one of the 30 participants. Her view to the diary is cited below.

\section{Mateboho: This book of yours (referring to a journal) has helped me to make my monthly budget. Can I use it even after your study?" \\ Researcher: Why? \\ Mateboho: At least now I know where my social grants go to. Before the journal use, I could not account for my finances because I did not bother to write my expenditures down.}

Mateboho further explained how the journal recording has helped her not to buy useless stuff like alcohol and "snuff", because she felt ashamed to write down what she had bought when this was R11 for quart of beer or R4.50 to fill her snuff-case, especially since it was not a lot of money. She would rather write that she has bought bread and mealiemeal than alcohol. "I was also ashamed what explanation I will give to my team having to account for my social grants," Mateboho explained.

One of the traditional chiefs interviewed, mentioned that the social grants have compromised community economic initiatives, and regarded as long-term benefits to rural communities. A local councillor who is also a member of a local church in Thaba-Nchu also alluded to the fact that community development interventions, which were started in order to ensure development of rural communities, had been abandoned in the 1990s, with the transition to the new political dispensation in South Africa. There are remnants of previously funded community projects in most of the rural villages of Thaba-Nchu. The rural development infrastructure, including farming implements; dilapidated livestock buildings, vandalised fencing and silos for grain storage, is no longer in use or of benefit to the communities. In the 1990s the

IInduna - sometimes referred as isiduna, or inkosana is a colonial position offered to a traditional headman, or a sub-chief. 
departments of agriculture and rural development gave community members some greenhouses to start vegetable gardening projects. By 2008, about 90 percent of the greenhouses had still not been used. The rural communities of Thaba-Nchu had abandoned the project.

\section{1 "Stokvels"2 and social grants}

The Gordon (2012) study on the social grant payment systems reveals that social grants are used in various ways, but predominantly grants are used to buy food, to pay school fees and other school-related expenses, water, electricity, transport, medical costs and accommodation. The study further emphasised that the government expects the recipients to be responsible spenders, and not to waste their remittances. How do the participants interpret this? As ABET practitioners we were particularly interested in the paying of school fees and other school-related expenses. Our interest lay in how school expenditure is done and explained by the rural women. School is for children, not for them. They have not even considered attending adult basic education and training literacy classes, which are free.

The study revealed that some recipients have joined stokvels, where people voluntarily join groups that function as fund-raising social clubs. Stokvels generate funds for members who are allowed to borrow money and repay it at a marginal interest rate. These schemes are commonly found in the townships and rural areas. They provide financial opportunities for people who are unemployed and, therefore, do not qualify for bank loans or other financial services provided by banks. Because it is well organised and managed by-laws, stokvels are reportedly widely used by social grant recipients. Gordon (2012) report recommends that initiatives that attract recipients' spending of their grants should be explored. This report, therefore, focused on stokvels to investigate whether it can be utilised to create some form of financial stability or economic empowerment for the recipients. A story by one member of the Boikhuco Women's Cooperative is cited below:

\subsection{Sellwane's story}

A sub-group of the Boikhuco Women's Cooperative started a social club. Each month, after receiving their social grants, the members would meet and decide who has to get the monthly contributions of R100 collected from each member. Thus, every month there is a total amount of R500 available and one member is given the money to invest on an incomegenerating activity of their choice. One member, Sellwane, decided to buy vegetables which she intended to sell in her community. Sellwane was able to generate an extra R100 profit from this activity, therefore, when she repaid the money, with the required R50 interest, she was left with another a R50 profit. She decided that next time, when it's her turn to get money, she will buy seedlings and plant her own vegetables rather than to buy and resell vegetables. For a moment Sellwane kept thinking about how she was going to get more money to buy seedlings. When she received the monthly social grant for her two boys, who were both abandoned by their father, Sellwane, who is 19 year, took the R560 (R280 per child, at the time) and bought the seedlings. Within a period of two years, Sellwane was already planting her third season of vegetables in her small garden. She realised that the garden was too small; she needed to plant more vegetables to meet the demand for vegetable in of her community. She spoke to a neighbour, a child-headed household, where three orphans were living by themselves. She was now planting vegetables in both her garden.

Soon Sellwane and the orphans were harvesting enough vegetables to feed themselves and to sell to her community. The three orphans Nthabiseng, Kopano and Khotso were could at least now eat vegetables with their pap, and could afford to save a little bit of their social grants to buy meat at least once a week. The vegetable gardening has helped them to use their social grants to buy meat and egg. Now they were able to include these proteins in their diet. Before the garden project they could only afford to buy vegetables from the market and did not have enough for other food-stuffs.

Sellwane, like Mateboho has, also benefited from the social grant and her vegetable garden by learning to use the journal/diary that was provided for her to record her financial expenses - something she had never done before. She has learnt that money has to be accounted for, regardless of how small the amount may be. Admittedly, the social grant is not a lot of money, but for most of the recipients, the majority of whom had not worked before, the social grants had become their sole source of income. For them, social grants seem like a lot of money and worth spending. Social grants contribute to poverty alleviation, not only for teenage mothers, but also for orphans and vulnerable children who are

${ }^{2}$ Stokvels are informal fund-raising social clubs where members benefit from borrowing with agreed interest on repayment. They are informal because the majority are not registered and they operate at a small scale, primarily for their members 
entirely dependent on them.

\section{Recommendations and Conclusion}

One of the fundamental principles of adult education is to empower individuals and communities to be self-reliant. During the two year journey with the social grants recipients in Thaba-Nchu, we have learned that many NGOs, including CARESouth Africa ${ }^{3}$ operate in the area on various community development interventions. CARE-South Africa has been working closely with the communities of Thaba-Nchu in various projects. One of the main projects was the "keyhole home gardening project and training. When CARE-SA was phasing out the Boikhuco community development, where it conducted training for income-generating projects including "keyhole home gardening" and others. CARE, unlike other organisations, organised a "seed-fund" for their various projects in which community members were given funds to augment their income-generating activities. This was done in order to sustain what was started through foreign aid. The Boikhuco Women Cooperative was given funds that were monitored before CARE left them. The women's cooperative augmented their stokvel project; the keyhole home gardening project was adopted by almost every household in the northern trusts and, more interestingly, the women's co-op had started a technological initiative for themselves and their community.

The Boikhuco Women's Cooperative started a small kiosk operating from one of their member's home. The kiosk started off selling airtime recharge coupons for mobile phones. Then the co-op bought a solar panel, to charge cellphones, and a television set, this was for the children, who pay a small fee to watch various programmes. What started as a small kiosk has grown into a big project. Today, the women even sell cell phones. A small rural village without electricity has become a developmental area where community members can access technological devices and live like urban dwellers.

As ABET practitioners we are proud of what adult education can do for people. These are social grants recipients who are now not solely relying on social grants to improve their livelihoods, but have become technologically savvy and use this to improve their lives and those of their communities. If social grants and foreign aid are used productively it can empower communities. The Boikhuco's story is one such example and this is also what was envisaged by Jeffrey Sach's Millennium Villages Project in Africa.

Recent studies on social grants and foreign aid in South Africa allude to the fact that these economic interventions are contributing substantively towards poverty reduction. This study concludes that in order to attain authentic sustainable development, community initiatives such as the Boikhuco Women's Cooperative should be extended and replicated. Social grant recipients should see the grant as a temporary intervention, while they consider long-term measures and projects that they can undertake which will have a sustainable impact. Foreign aid agencies should also look at communities and engage with them in a manner that is empowering and which allows the community to thrive. When they depart, they should leave the community with sustainable development programmes. Social grants and foreign aid should be empowering interventions that can be used to achieve a developmental and capable state. Chiwengo (2007:192) observes, "Contemporary South Africa continues to be a site of socioeconomic exclusion, community marginalisation, eroding family relationships, increasing crime and increasing mistrust among communities." Whichever policy the government propagates, the issue of poverty alleviation, particularly in poor rural areas, remains a daunting and recurring challenge for policy-makers. This is said in light of the three economic poverty indicators perpetual poverty, joblessness or high unemployment and inequalities amongst its society.

In South Africa the debate continues about the phenomenon of absent fathers and the consequential social impact this has on society. It has left the country with huge challenges regarding social cohesion, moral degeneration, sound family values and societal code of conduct. The legal system has to address this phenomenon of absent fathers more seriously than has been the case thus far. Fathers and parents' not fulfil their financial responsibilities to their children and therefore the state has to intervene through the provision of social grants. South Africa has become a welfare state.The misconception that social grants are a gift and should therefore be spent and not saved should be dispelled, as it is misleading. Rather, the government and international NGOs should intensify community education programmes aimed particularly at the youth and teenage mothers who receive social grants, to ensure a better future for them. They should also assist communities by collaborating with them in income-generating projects that would sustain their livelihoods and economic base.

${ }^{3}$ CARE-South Africa is part of CARE international NGO operating in 84 countries and reaching more than 83 million people worldwide. It started its operation in South Africa in 1994. 
This article aims to contribute to the debate around social grant issues. The government requires empirical evidence to constantly review policies governing social grants and how long-term benefits can be established from them. Whilst this paper may not be a national representation, due to its sample limitation, the results on the usage of social grants will add value, in clarifying some of the misconceptions raised above.

\section{Acknowledgement}

Names used in this article are not real names. This is done to protect the participants' identities.

\section{References}

Breaking through the Millennium Villages Project: The Next Five Years: 2011 - 2015 (2012) Retrieved from http://www.millenniumvillages.org

Chiwengo, N. (2007). Understanding Cry, the Beloved Country. A student casebook to issues, sources and historical documents. London: Greenwood Press.

Cohen, L., \& Manion, L., \& Morrison, K. (2010). Research methods in education. 6th edition. London: Routledge.

Department of Rural Development and Land Reform. Comprehensive rural development programme - strategic plan 2009-2012, Retrieved from http://www.ruraldevelopment.gov.za

Fritz V., \& Menochal A. (2007). Developmental states in the new millennium. Development Policy Review 25(5):531-552.

Heintz J \& Lund F (2012). Welfare regimes and Social Policy: A Review of the Role of Labour and Employment. Gender and Development Programme E-Paper(17) 1 - 28.

National Development Plan: Vision for 2030. (2011). Retrieved from http://www.thepresidency.gov.za

Progressus Research Development Consultancy and Gordon R. (2012). The payment experience of social grants beneficiaries. FinMark Trust. North Cliff Johannesburg

Ritcher, L. \& Morrell, R. (2008). Fathering: the role of men in raising children in Africa - holding up the other half of the sky. In Africa's future, Africa's challenge edited by M. Garcia, A. Pence and J. Evans. The World Bank, pp. 162 - 188.

Statistics South Africa (2012). 2011 National Census. Retrieved from http://statisticssouthafrica.info/about/people/population.htm

Thompson, L. (2001). A history of South Africa, Cape Town: Jonathan Ball

UNISA (2009), Managing Adult Basic Education \& Training in Context for Development Reader. Pretoria 